\title{
Experience of Nursing Diploma Student Learning NCLEX through Distance Learning
}

\author{
Arina Qona'ah \\ Airlangga University \\ Surabaya, Indonesia \\ arinaqonaah@yahoo.co.id
}

\begin{abstract}
NCLEX is a competency test for a nurse who wants to get a license as a professional nursing. NCLEX measures the ability of a nurse safely and effectively nursing. In nursing diploma institution, there is no material which discusses NCLEX. Therefore, this institution needs to prepare the students by following distance learning. This study aimed to explore the experience of nursing diploma students preparing NCLEX through a distance learning. A qualitative interpretive phenomenology approach was applied as the research design. Purposive sampling technique was chosen to get the participants according to the inclusion criteria. There were six participants involved in this study. The data collection method used the semistructured interviews and recording devices. The data were analyzed by applying Braun and Clarke Thematic Analysis. Four overarching themes emerged from this study. The themes included comparing the science of nursing, getting a new perception of NCLEX, obstacles in language and the need of adequate facilities. Distance learning is one of the learning innovation to facilitate the material that arenot obtained in the institutions. Based on the students' experiences, the distance learning gives a new experience for the students in the aspect of nursing science in the other countries and makes a comparison of that. The students have a new perspective of NCLEX, particularly, about the importance of NCLEX. Supporting the distance learning needs the adequate facilities and the students' ability of English mastery.
\end{abstract}

Keywords-Diploma Nursing Student, NCLEX, Distance Learning

\section{INTRODUCTION}

The globalization era, especially the enactment of the Asean Economic Community (AEC) gives a huge impact in the health sector. Health workers have a free to mobilize at home and abroad. In the face of AEC, Indonesia has to work hard in increasing the competitiveness and professional health workers to make them equal with those of the other countries.

Nurse is a health worker that has the highest proportion in Indonesia. The number of the nurses registered in MTKI per August 2016 was 441.285. The number of the nurses was disproportionate with the job opportunities available in the country wherein 2015, the number of the nurses who work in hospitals and community health center was 223.910 [1]. Hence, the government is required to increase the job opportunities for the nurses; one of them is by pushing the placement of the nurses to go abroad.
The Ministry of Health said that the needof nurses in the foreign countries is still high. For example, Saudi Arabia needs 500 nurses, Kuwait needs 400 emergency nurses and 1000 nurses, Japan needs 1000 nurses. The majority of Indonesia nurses demand from the foreign countries could not be fulfilled. In 2010 - 2014, the demand for nurses abroad was about 15.431 people while the realized ones were $5.625(36,5$ $\%)(\mathrm{BNP} 2 \mathrm{TKI})$

Indonesian nurse has a high opportunity to work abroad due to the high demand in the foreign countries. The other countries commonly like the characteristic of Indonesian human resources. The opportunities of Indonesian nurse to work outside the country are available in some countries such as North America (USA, Canada, Mexico, Suriname), Eastern Asia (Kuwait, Qatar, UEA, Saudi Arabia, Bahrain), Europe (British, Dutch, Belgium, Spain, Germany), Oceania (Australia), Africa (Sudan, South Africa and Namibia) [2].

According to the Rule of the Ministry of Health of the Republic of Indonesia No. 47/2012 on sending the nurse abroad, the requirements that must be fulfilled by the nurses who work abroad is having a certificate of registration because they possess the knowledge and good skill, discipline, and comply the code of conduct professional. Another requirement is having the certificates of foreign language, certificates of the ability to use the information technology, and certificates of skill. Besides this requirement, a nurse who will go abroad must also meet the terms and conditions set by the state users. Another requirement is to pass international competency test held by the intended such as NCLEX.

One of the obstacles faced by the Indonesian nurses in the foreign countries is the ability to accomplish the international competency test. The results of the tryout test of NCLEX in Bandung done by 68 participants was, none of them passed this test. The Indonesian nurses are still lack of the capacity to pass the international competency test in terms of both language and material [3].

The preparation of the nurses to face NCLEX competence test is not provided by the academic institutions because most of the preparations of the competency test are executed by the national competency test. Hence, the students need to learn independently to prepare for the test of NCLEX. One of the kind of preparations that can be done by is students is joining a distance learning. Distance learning is a planned teaching/learning experience that uses a broad spectrum of 
technology to reach students in the long distance and it is designed to encourage the interaction students to learn, interact and get certificate.

The phenomenon of the international competency test of nursing diploma students is largely not known by the NCLEX. Based on the theory and phenomenon associated with the international competency, the researcher needs to conduct a research on the nursing diploma students' experience against the NCELX through a distance learning.

\section{METHOD}

The design used in this research was a qualitative approach with an interpretative phenomenology . Interpretative phenomenology interpretative is a phenomenology that insists on interpreting and understanding the human's life experience. This study was conducted at Nursing Diploma in Lamongan. The participants in this research were chosen by using purposive sampling technique which is appropriate for the inclusion criteria. The inclusion criteria in this research this is a last semester-student of nursing diploma in Lamongan, who follows the distance learning, is able to communicate using Indonesian and is willing to become the participants and provide information about their experiences related to the distance learning. The number of participants in this research was six participants. The data collection method was the semistructured interviews and using recording devices. The data were analyzed by applying Braun and Clarke Thematic Analysis [4].

\section{RESULT AND DISCUSSION}

\section{A. Comparing theNursing Science}

Nursing is an applied science that uses a variety of knowledge, the concept, and principle of various groups of science. The nursing sciences existing in the world have the same basic and concept which have to meet the needs of the related basic human's response to a healthy and sick condition. The concept of nursing in every country is adjusted to the culture of as well as the rule in the country. The theme of comparing the nursing science is drawn up by two sub-themes namely nursing around the word and the different aspect of legality.

"Ilmu keperawatan di Indonesia atau mungkin di luar negeri itu kayak apa.. Mungkin ada perbedaan atau tidaknya itu saya bisa tahu lagi...” (P1)

“.. selain itu mungkin kalau masalah legalitas yang dalam soal itu mungkin yang diceritakan itu yang dari Filipina,..." (P3)

Nursing is a form of professional service as an integral part of health services based on the science and art, giving the biopsychosocial and spiritual aspects, addressed to an individual, family and local people, of illness or health, which includes the whole processes of human life. Nursing is an applied discipline that is implemented differently correlated to the social, cultural and political aspects where the nursing is practiced [5].
The nurse uses the basic science as the guideline for rationalizing developed by the nurses so that they know what, why and how the nursing care must be implemented or given to the client. The success of the professional nurses delivery highly depends on their ability of synthesizing various sciences and applying them to a form of professional services.

Every country has different rules regarding the nursing practice. The aspect of legality is probably one of the things that should be considered when holding a nursing practice in a country. According to a Kamus Besar Bahasa Indonesia (Big Dictionary of Indonesian Language), legality means the validity of and regarding his legal [6]. In every country, the nursing practice is arranged by its regulation. A nurse must be able to give the professional nursing services to the public. This condition is will directly cause the consequences of law in nursing practice. Therefore, in their practice, the nurses are bound by the rule of law, ethical and moral values [7].

\section{B. New Perception of NCLEX}

Perception is the act of collating, recognizing and interpreting the sensory information to give the image and understanding of environment [6]. Someone who has not known and understood something they may have the wrong perception. The experience of joining NCLEX through distance learning will change the students' perception students to the NCLEX test. The theme of getting a new perception of NCLEX is formed by three sub-themes that are different from the national competency examination, more difficult than the usual examination, and needs to improve the knowledge and skill.

“...Bagaimana cara menjawab, terus bagaimana kalau benar itu warna hijau kalau salah itu warna merah, terus waktunya.. waktu ujian, hasilnya, ..." (P6)

"Ya.. materinya lebih dalam.. gitu bu.. kita kan D3 biasanya kan Cuma sekilas saja.. itu kebanyakan pembahasannya dalam.." (P4)

NCLEX test is different from the national competency test of nurses in Indonesia. National Competency test for nursing diploma students uses a paper-based method while the NCLEX uses the CAT (Computer Adaptive Test). According to the participants $\mathrm{t}$ joining the distance learning, they get an experience on how to do an NCLEX test technically. The participants reported that the NCLEX is more difficult than the national competency test of the nurses so as to be successful, they have to increase their knowledge and skills as well as the frequency of doing the NCLEX.

NCLEX is an examination system using computerizedbased method to know the ability of a nurse regarding the cognitive aspect, skill (nursing procedure) and attitude so that the nurse can safely and effectively provide a nursing care service. The computerized-based method was in 1994 in the United States and it has some branches in the states appointed by an agreement of the National Council of State Boards of Nursing (NCSBN). The scores of NCLEX test will be the basis for NCSBN in giving a license as Register Nurse (RN) or Practical Nursing (PN) [8]. 
Research on the preparation of competency test to the nursing students done by [9] showed that learning using simulation cases method can improve the students' ability in the face of the competency test up to $50 \%$. The success in learning must be supported by the institutions; for example provisions for the theory, and equipment of the laboratory supporting to create the clinical conditions. Another preparation can also be implemented by training the students to do an online test

\section{Obstacle in Language}

Distance learning for nursing diploma student has some obstacles. One of them is language. English is the introductory language used in the distance learning, in both exams and college. The students who do not have the English ability may get lost in following this program. The obstacle in language is arranged by two sub-themes anamely misunderstanding of the case and difficult meaning of the sentence.

“...kendala dalam menerjemahkan soalnya. Sebenarnya soalnya simple tapi karena kita sulit menerjemahkan...” (P3) (P6)

“. kan ada kosakata yang masih belum paham artinya "

The participants underwent the problem of language when joining the distance learning, that is the the introductory part using the English. The participants experienced the difficulty when they translated NCLEX even though they had ever got such material at college but because they did not understand the intent they could not work on such situation. They have an erroneous perception of the material and material obtained.

According to [10], the obstacles in NCLEX test license are the language and readiness of Indonesian nurses. Language is one of the significant components for the success of NCLEX test. The participants' ability to speak English is necessary to understand the NCLEX [11]. English ability, both in passive and active, plays a very essential role to successfully select to work abroad.

\section{Need of Adequate Facilities}

Learning will be effective if it is supported by facilities. The facility is everything, physical thing and material, to facilitate the implementation of the learning process. Distance learning should be supported by room, audio, and internet connection. Good facilities will ease the learning process. The needs of adequate facilities are compiled by two sub-themes including unstable internet connection and less of supporting facilities.

“.. tapi jaringan koneksi internetnya.. Seumpama nanti koneksi internetnya terputus berarti nanti kita mungkin tidak bisa mengikuti slidenya itu..seperti itu tadi.. jadi mungkin tertinggal" (P3)

"Koneksi internetnya kadang - kadang suaranya putus putus" (P2)

"ee.. tadi kan.. enak kalau bisa mengerjakan misalnya di sini ada apa ... laptopnya mencukupi untuk ujian..” (P4)
The institution does not provide adequate facilities when holding the distance learning. The inadequate facilities is due to the unstable network connection and a means of inadequate supporting facilities. The supporting facilities that should be provided in distance learning are loudspeaker and computer.

Distance learning in Indonesia still have some obstacles in terms of facilities and human resources. Some obstacles are the students' low consistency, the low infrastructure of internet network, the English mastery, the staff who are not yet ready and the mindset of communities which is still oriented on the conventional education. The low level of independence supervision and students can cause the learners' low consistency in following the distance learning. Many students cannot continue the distance learning. The infrastructure of the internet connection or the internet access are difficult to obtain. The telephone network is still not available in the various areas in Indonesia [12].

\section{CONCLUSIONS}

Distance learning is one of the alternative methods to learn that can be applied to improve the quality of education included in the preparation of college students to face the globalization era. The nursing diploma students get some experiences when they undertake the test of NCLEX using distance learning such as getting a new perception of NCLEX and an overview of how to do NCLEX test and understanding the nursing in several countries.

The obstacles faced by the students during NCLEX online training is the lack English ability and inadequate facilities. The institution should be given adequate facilities to create an effective and efficient learning process.

\section{REFERENCES}

[1] "Profil Kesehatan Indonesia Tahun 2015," Kementerian Kesehatan Republik Indonesia, 2016. .

[2] O. F. Rosyati, "Strategi Kemenkes dalam Pendayagunaan Tenaga D III Keperawatan Menghadapi MEA," in Kongres Nasional II AIPDIKI, 2017.

[3] Y. Yektiningtyastuti, "Improvement of Quality Standards of Professional Competency of Indonesian Nurses to International Standard," Semarang, 2016.

[4] V. Braun and V. Clarke, "Using thematic analysis in psychology," Qual. Res. Psychol., vol. 3, no. 2, pp. 77-101, 2006.

[5] A. A. Hidayat, Pengantar konsep dasar keperawatan. jakarta: salemba medika, 2004.

[6] E. Setiawan, “Kamus Besar Bahasa Indonesia (KBBI)," 2012. .

[7] D. A. Sudrajat, “Aspek hukum praktik keperawatan. Jurnal Kesehatan Kartika Stikes A. Yani,” pp. 9-19, 2009.

[8] R. Aryani, "FIK-UI Menyiapkan Uji NCLEX-RN untuk Mahasiswanya, Mungkinkah?,” 2010.

[9] J. K. Hayden, R. A. Smiley, M. Alexander, S. Kardong-Edgren, and P. R. Jeffries, "Supplement: The NCSBN National Simulation Study: A longitudinal, randomized, controlled study replacing clinical hours with simulation in prelicensure nursing education," J. Nurs. Regul., vol. 5, no. 2, pp. C1-S64, 2014. 
[10]E. Novriadi, S. Safarudin, and A. Komala, "Hubungan Studi Berbasis Kompetensi Dengan Uji Lisensi Berdasarkan NCLEX-RN, Kesiapan MenghadaPI ASEAN EC 2015, dan Pasar Kerja Keperawatan Global Di Prodi S1 Keperawatan STIKES YARSI Pontianak,” 2014. .

[11]D. Finfgeld-Connett and E. D. Johnson, "Literature search strategies for conducting knowledge-building and theory-generating qualitative systematic reviews," J. Adv. Nurs., vol. 69, no. 1, pp. 194-204, 2013.

[12]A. K. Attri, "Distance education: problems and solutions," Int. J. Behav. Soc. Mov. Sci., vol. 2, no. 40, pp. 103-113, 2012. 